\title{
Laporan Penelitian
}

\section{Korelasi ekspresi IL-6 dengan STAT3 pada metastasis penderita KNF WHO tipe 3 LMP-1 positif}

\author{
Soehartono, Monika Teresa Prasetyo, Hendradi Surjotomo, Hendy Setyo Yudhanto \\ Departemen Departemen Ilmu Kesehatan Telinga Hidung Tenggorok-Bedah Kepala dan Leher \\ Fakultas Kedokteran Universitas Brawijaya/ Rumah Sakit Dr. Saiful Anwar \\ Malang
}

\begin{abstract}
ABSTRAK
Latar belakang: Karsinogenesis karsinoma nasofaring sangat kompleks, dan disebabkan oleh interaksi antara infeksi kronis Epstein-Barr Virus (EBV), faktor lingkungan, dan perubahan genetik serta epigenetik. Latent Membrane Protein (LMP)-1 merupakan antigen utama EBV. LMP-1 diyakini menstimulasi ekspresi sitokin yang memengaruhi perilaku sel epitel, salah satunya adalah Interleukin (IL)6. IL-6 akan mengaktivasi jalur Signal Transducer and Activator of Transcription (STAT)3. Peningkatan ekspresi IL-6 dan STAT3 memiliki kaitan erat dalam lingkungan mikro tumor KNF, namun peran IL-6 dan STAT3 dalam modulasi migrasi dan invasi sel KNF masih belum jelas diketahui. Tujuan: Mengetahui korelasi antara ekspresi IL-6 dan ekspresi STAT3 di jaringan nasofaring dengan metastasis penderita KNF WHO tipe III LMP-1 positif. Metode: Penelitian observasional analitik dengan pendekatan cross-sectional yang melibatkan 15 penderita KNF WHO tipe III LMP-1 positif. Pemeriksaan ekspresi LMP-1, IL-6, dan STAT3 menggunakan metode pewarnaan imunohistokimia, dan hasilnya dihitung dengan menggunakan software ImmunoRatio. Penentuan stadium klinis metastasis berdasarkan pemeriksaan klinis dan penunjang radiologis, kemudian dievaluasi nilai TNM menggunakan AJCC 2017. Hasil: Analisis statistik ekspresi IL-6 dan STAT3 menunjukkan korelasi yang signifikan $(\mathrm{p}=0,020)$ dengan koefisien korelasi $\mathrm{r}=0,592$. Tidak terdapat perbedaan ekspresi IL-6 yang bermakna di antara penderita stadium III, IVa, dan IVb $(\mathrm{p}=0,116)$. Terdapat perbedaan ekspresi STAT3 yang signifikan di antara penderita dengan stadium III, IVa, dan IVb $(p=0,038)$. Kesimpulan: Semakin tinggi ekspresi IL-6 maka ekspresi STAT3 pada jaringan nasofaring penderita KNF WHO tipe III LMP-1 positif semakin meningkat. Semakin tinggi stadium klinis, maka ekspresi STAT3 pada jaringan nasofaring penderita KNF WHO tipe III LMP-1 positif akan meningkat.
\end{abstract}

Kata kunci: karsinoma nasofaring, Virus Epstein-Barr, LMP-1, IL-6, STAT3

\begin{abstract}
Background: Carcinogenesis of NPC is complex interactions among chronic EBV infection, environmental factors, genetic and epigenetic. LMP-1 is EBV's antigen most expressed in NPC cases. LMP-1 is believed to stimulate expression of cytokines that affect the behavior of epithelial cells, i.e. Interleukin-6 (IL-6) which will activate the STAT3 pathway. Increased expression of IL-6 and STAT3 has a close relationship in tumor microenvironment of NPC patients, but the role of IL-6 and STAT3 themselves in modulation of migration and invasion of NPC cells are not yet fully understood. Purpose: To find out the correlation between IL-6 expression and STAT3 expression in the nasopharyngeal tissue of NPC patients with LMP-1 positive metastatic WHO type III. Method: Observational analytic study with cross-sectional approach involving 15 patients WHO type III LMP-1 positive NPC patients. Examination of LMP-1, IL-6, and STAT3 using immunohistochemical, and the results were calculated using ImmunoRatio. Clinical staging of metastases based on clinical examination and radiological imaging then synchronized with AJCC 2017. Result: Expressions of IL-6 and STAT3 showed significant correlation ( $p=0.020)$ with coefficient $r=0.592$. There were no differences in IL-6 expression among patients with stage III, IVa, and $\operatorname{IVb}(p=0.116)$. There were significant differences in STAT3 expression among patients with stage III, IVa, and IVb ( $p=0.038)$. Conclusion: There was a significant positive correlation between IL-6 and STAT3 in tissue from WHO type III LMP-1 positive NPC patients. The higher the clinical stage, the expression of STAT3 in the nasopharyngeal tissue of positive WHO type III LMP-1 NPC patients will increase.
\end{abstract}


Keywords: nasopharyngeal carcinoma, Epstein-Barr Virus, LMP-1, IL-6, STAT3

Alamat korespondensi: Monika Teresa Prasetyo, Bagian Ilmu Kesehatan Telinga Hidung Tenggorok Bedah Kepala dan Leher Fakultas Kedokteran Universitas Brawijaya/ RSUD Dr. Saiful Anwar Malang, Indonesia.Email: monika.teresa@hotmail.com.

\section{PENDAHULUAN}

Karsinoma nasofaring (KNF) adalah karsinoma sel skuamosa yang berasal dari epitel mukosa nasofaring dengan diferensiasi buruk dan kecenderungan kuat untuk bermetastasis ke kelenjar getah bening regional dan/atau organ yang jauh. Neoplasma ini lebih sering timbul di dinding lateral nasofaring, lebih tepatnya di fossa Rosenmuller. ${ }^{1,2}$

KNF di dunia merupakan keganasan yang relatif jarang terjadi dengan angka kejadian kurang dari 1:100.000. KNF didapatkan tinggi pada populasi ras Mongoloid terutama yang tinggal di Cina Selatan dan yang telah berimigrasi ke negara-negara lain termasuk Asia Tenggara. ${ }^{1}$ KNF di Indonesia merupakan tumor ganas terbanyak di daerah kepala dan leher, dengan insiden kasus baru pada pria sebanyak 9,4 kasus per 100.000 penduduk per tahun, dan pada wanita sebanyak 3,8 kasus per 100.000. ${ }^{3}$ Penelitian di Rumah Sakit Umum Daerah (RSUD) Dr. Soetomo Surabaya selama 4 tahun, didapatkan penderita KNF sebanyak $41,9 \%$ dari seluruh penderita tumor ganas kepala-leher. ${ }^{4}$ Sementara di Divisi Onkologi THT RSUD Dr. Saiful Anwar Malang (RSSA) didapatkan kasus baru KNF sebanyak 44,3\% dari seluruh kasus baru tumor ganas kepala-leher selama 3 tahun.

Epstein-Barr Virus (EBV) diyakini memiliki peran onkogenik dalam KNF yang ditunjukkan dengan adanya peningkatan titer IgG dan IgA pada penderita KNF terhadap EBV viral capsid antigen (VCA) dan antigen yang berhubungan dengan replikasi yang disebut early antigen (EA). Latent membran protein 1 (LMP-1) merupakan suatu efektor kunci dari transformasi neoplastik sel B dimediasi EBV dan diekspresikan pada $65 \%$ kasus, namun infeksi EBV saja tidak cukup untuk menginisiasi tumorigenesis KNF. ${ }^{1,3,5}$

Berbagai penelitian menunjukkan invasi dan metastasis KNF disebabkan oleh adanya ekspresi LMP-1. LMP-1 terbukti terlibat dalam regulasi ekpresi protein yang dikaitkan dengan metastasis seperti E-cadherin, matrix metalloproteinase (MMP), c-Met, Vascular endothelial Growth Factor (VEGF), Epidermal Growth Factor Receptor (EGFR) dan cyclooxygenase-2 dengan memicu jalur pertahanan hidup sel dan jalur proliferasi termasuk Janus Tyrosine Kinase (JAK) / Signal Transducer and Activator of Transcription (STAT). ${ }^{6}$

LMP-1 juga diyakini menstimulasi ekspresi faktor pertumbuhan sitokin yang dapat memengaruhi perilaku sel epitel. Sitokin pro inflamasi ini diketahui mengalami peningkatan ekspresi pada epitelium yang meradang dan hiperproliferasi. Tidak hanya berpartisipasi dalam rekrutmen leukosit, sitokin juga memodulasi migrasi dan proliferasi sel epitel. ${ }^{5}$

Interleukin (IL)-6 adalah sitokin mempunyai peran penting pada banyak aktivitas biologis. ${ }^{7}$ IL-6 diketahui terlibat dalam proliferasi dan diferensiasi berbagai sel tumor ganas. Ekspresi yang tinggi pada IL-6 maupun reseptornya (IL-6R dan IL6R) juga terbukti mempromosikan migrasi dan invasi dari sel kanker dan meningkatkan ekspresi dari MMP khususnya MMP-2 dan MMP-9. ${ }^{8}$ Penelitian juga menunjukkan bahwa peningkatan serum IL-6 memiliki kaitan erat dengan metastasis jauh pada penderita KNF, 
namun peran IL-6 sendiri dalam modulasi aktivitas migrasi dan invasi sel KNF masih belum diketahui secara jelas. ${ }^{9}$

Signal Transducer and Activator of Transcription (STAT) 3 terbukti terlibat dalam perkembangan tumor manusia termasuk keganasan kepala dan leher. STAT3 mempromosikan inisiasi dan progresi kanker dengan cara menghambat apoptosis atau menginduksi proliferasi sel, angiogenesis, invasi dan metastasis. Aktivasi STAT3 oleh IL-6 diketahui memegang peranan penting pada stadium awal peradangan yang dikaitkan dengan kanker. ${ }^{10}$ Aktivasi STAT3 juga diyakini berhubungan dengan meningkatnya perilaku ganas dan invasif dari sel. Aktivasi STAT3 dapat meningkatkan ekspresi MMP yang meningkatkan metastasis suatu keganasan melalui degradasi proteolitik dari matriks ekstrasel. ${ }^{8,11}$

Berdasarkan latar belakang yang telah disebutkan di atas dan belum adanya penelitian mengenai korelasi ekspresi IL-6 dan ekspresi STAT3 dengan mekanisme metastasis penderita KNF WHO tipe III LMP1 positif, penulis tertarik untuk melakukan penelitian yang bertujuan untuk mengetahui apakah jalur sinyal IL-6 - STAT3 memiliki peran dalam menyebabkan terjadinya invasi dan migrasi pada KNF WHO III dengan LMP1 positif. Hasil dari penelitian ini diharapkan dapat melengkapi penelitian lain mengenai peran IL-6 dan STAT3 pada KNF WHO tipe III dalam patomekanisme metastasis.

\section{METODE}

Penelitian ini merupakan penelitian observasional analitik, pendekatan crosssectional dengan melakukan pemeriksaan ekspresi IL-6, dan STAT3 serta stadium klinis khususnya metastasis pada pasien KNF WHO tipe III LMP-1 positif. Sampel penelitian ini adalah preparat histopatologis penderita KNF yang datang ke Poliklnik THT RSSA dan telah dilakukan pemeriksaan histopatologis dengan hasil WHO tipe III, pemeriksaan radiologis untuk mengetahui stadium penyakit, serta belum mendapatkan terapi.

Penelitian dilakukan di Laboratorium Patologi Anatomi RSSA dan Laboratorium Patologi Anatomi Fakultas Kedokteran Universitas Brawijaya, Malang setelah mendapatkan persetujuan layak etik. Berdasarkan perhitungan didapatkan besar subjek penelitian minimal sebanyak 13 orang dan pengambilan sampel pada penelitian ini menggunakan teknik simple random sampling.

Kadar LMP-1, IL-6 dan STAT3 didapatkan dari jaringan nasofaring WHO tipe III yang dilakukan pemeriksaan imunohistokimia dengan antibodi primer merk dagang Santa Cruz Biotechnology Inc, lalu dilihat keberadaannya di membran dan sitoplasma sel dengan pulasan berwarna coklat untuk LMP-1 dan IL-6. Sedangkan untuk STAT3 dilihat keberadaannya di inti sel dengan pulasan berwarna coklat. Kesemuanya diinterpretasikan menggunakan perangkat lunak ImmunoRatio dengan menghitung 10 lapangan pandang dan diambil reratanya lalu disajikan dalam satuan persen.

Metastasis dibagi menjadi metastasis regional $(\mathrm{N})$ dan metastasis jauh $(\mathrm{M})$ yang dinilai berdasarkan pemeriksaan klinis dan penunjang radiologis (CT scan kepala leher, USG abdomen, dan foto Rontgen toraks PA). Stadium klinis KNF merupakan sistem penilaian KNF berdasarkan pemeriksaan klinis dan radiologis lalu dievaluasi nilai $\mathrm{T}, \mathrm{N}$, dan M yang mengacu pada AJCC tahun 2017.

Semua data yang diperoleh akan diolah menggunakan program Statistical Package for the Social Sciences (SPSS) versi 23.0. Normalitas variabel diuji dengan menggunakan uji Shapiro Wilk. Untuk mengetahui korelasi ekspresi IL-6 dengan STAT3 menggunakan uji Pearson, untuk mengetahui perbedaan ekspresi IL-6 dan STAT3 diantara kelompok stadium klinis penderita KNF WHO tipe III menggunakan uji one-way ANOVA. 


\section{HASIL}

Penelitian dilakukan pada bulan Oktober 2018 hingga Februari 2019 dengan jumlah sampel penelitian 15 orang yang memenuhi kriteria penelitian. Karakteristik umum subjek penelitian meliputi jenis kelamin, kelompok usia, status pekerjaan, kebiasaan merokok, dan makan ikan asin yang tercantum dalam tabel 1. Karakteristik stadium klinis subjek penelitian ini dilihat berdasarkan T, N, dan M yang mengacu kepada AJCC 2017 (tabel 2).

Pada pemeriksaan IHK, ekspresi LMP1 dan IL-6 berupa pulasan coklat yang didapatkan terutama pada membran sel dan sitoplasma, sedangkan ekspresi STAT3 berupa pulasan coklat pada sitoplasma dan inti sel. Ekspresi LMP-1 dinilai secara kuantitatif terlebih dahulu dengan menggunakan perangkat lunak ImmunoRatio ${ }^{\circledR}$ lalu dinilai secara kualitatif. Cut-off nilai immunoreaktif LMP-1 menggunakan kriteria sesuai dengan penelitian oleh Kitagawa, ${ }^{12}$ yang menyatakan positif bila nilai imunoreaktif $>10 \%$ dan negatif bila $<10 \%$. Menurut penelitian Sarac, yang dikutip oleh Chen et al. ${ }^{13}$ LMP-1 dapat dapat dikatakan positif bila didapatkan pulasan coklat yang terdeteksi berapapun nilai imunoreaktifnya. Semua sampel jaringan nasofaring subyek penelitian didapatkan hasil positif dengan nilai imunoreaktif LMP-1 terendah $23,46 \%$ dan tertinggi $84,84 \%$.

Ekspresi IL-6 dengan pemeriksaan IHK jaringan nasofaring didapatkan pulasan coklat terutama pada membran sel dan sitoplasma sel. Pulasan coklat juga ditemukan tersebar di sekitar cancer nest. Menurut Jinno et al. ${ }^{14}$ ekspresi IL-6 dibedakan menjadi tiga kelompok yaitu negatif, positif lemah, dan positif kuat. Cut-off nilai imunoreaktif menyatakan ekspresi IL-6 negatif bila nilai imunoreaktif $<5 \%$, positif lemah bila $5 \%$ $30 \%$, dan positif kuat bila $>30 \%$. Ekspresi

Tabel 1. Karakteristik umum subjek penelitian

\begin{tabular}{lcc}
\hline \multicolumn{1}{c}{ Karakteristik umum } & n & \% \\
\hline Jenis kelamin & 12 & 80 \\
$\quad$ Laki-laki & 3 & 20 \\
Perempuan & & \\
Kelompok usia & 1 & 6,66 \\
$\quad$ Dewasa awal (26-35 tahun) & 3 & 20 \\
Dewasa akhir (36-45 tahun) & 7 & 46,66 \\
Lansia awal (46-55 tahun) & 1 & 6,66 \\
Lansia akhir (56-65 tahun) & 3 & 20 \\
Manula (> 65 tahun) & & 26,66 \\
Pekerjaan & 4 & 73,3 \\
Tidak bekerja & 11 & 60 \\
Bekerja & & 40 \\
Merokok & 9 & 60 \\
$\quad$ Ya & 6 & 40 \\
$\quad$ Tidak & & \\
Ikan asin & 9 & \\
Ya & 6 & \\
Tidak & & \\
\hline
\end{tabular}


Tabel 2. Stadium klinis subjek penelitian

\begin{tabular}{|c|c|c|c|}
\hline & Stadium klinis & n & $\%$ \\
\hline \multicolumn{4}{|l|}{$\mathbf{T}$} \\
\hline $\mathrm{T} 2$ & & 7 & 46,66 \\
\hline T3 & & 4 & 26,66 \\
\hline $\mathrm{T} 4$ & & 4 & 26,66 \\
\hline \multicolumn{4}{|l|}{$\mathbf{N}$} \\
\hline N1 & & 4 & 26,66 \\
\hline $\mathrm{N} 2$ & & 3 & 20,00 \\
\hline N3 & & 8 & 53,33 \\
\hline \multicolumn{4}{|l|}{$\mathbf{M}$} \\
\hline M0 & & 12 & 80,00 \\
\hline M1 & & 3 & 20,00 \\
\hline \multicolumn{4}{|c|}{ Stadium } \\
\hline III & & 4 & 26,66 \\
\hline IVa & & 8 & 53,33 \\
\hline $\mathrm{IVb}$ & & 3 & 20,00 \\
\hline
\end{tabular}

IL-6 dinilai secara kuantitiatif dengan menggunakan perangkat lunak ImunoRatio ${ }^{\circledR}$. Didapatkan 13 subjek penelitian yang memiliki ekspresi IL-6 positif kuat dengan nilai imunoreaktif tertinggi sebesar $80,41 \%$ dan terdapat 2 subjek penelitian yang memiliki ekspresi IL-6 positif lemah yaitu masing-masing dengan nilai imunoreaktif $21,56 \%$ dan $21,4 \%$.

Ekspresi STAT3 dengan pemeriksaan IHK jaringan nasofaring didapatkan pulasan coklat pada inti sel. Pulasan coklat juga terdapat tersebar luas di sekitar cancernest. Ekspresi STAT3 pada penelitian ini didapatkan nilai imunoreaktif tertinggi adalah $45,57 \%$ dan nilai imunoreaktif terendah adalah $3,48 \%$.

Berdasarkan pengujian untuk hubungan antara ekspresi IL-6 dengan ekspresi STAT3 pada jaringan biopsi penderita KNF WHO tipe III LMP-1 positif menggunakan uji Pearson, menunjukkan nilai koefisien korelasi sebesar 0,592 dengan nilai signifikansi (p) sebesar 0,020 yang lebih kecil dari alpha 0,05 $(p<0,05)$, sehingga dapat disimpulkan bahwa ada hubungan yang signifikan antara ekspresi IL-6 dengan ekspresi STAT3 pada jaringan biopsi penderita KNF WHO tipe III LMP-1 positif, dengan arah korelasi bernilai positif.

Sejumlah 12 dari 15 subjek penelitian ini didapatkan belum bermetastasis jauh (M0) dan hanya 3 pasien yang sudah mengalami metastasis jauh (M1). Pada 12 pasien sudah bermetastasis regional (N1, N2, N3) saja tanpa metastasis jauh. Pada penelitian ini, uji t tidak berpasangan dilakukan untuk mengetahui perbedaan ekspresi IL-6 antara pasien KNF M0 dengan M1. Mean ekspresi IL-6 pada pasien dengan M0 adalah 46,21 $\pm 18,19 \%$ dan pada pasien M1 adalah $72,19 \pm 7,22 \%$. Terdapat perbedaan signifikan antara mean ekspresi keduanya $(\mathrm{p}=0,034)$. Uji t tidak berpasangan juga dilakukan untuk mengetahui perbedaan ekspresi STAT3 antara pasien KNF M0 dengan M1. Mean ekspresi STAT3 pada pasien dengan $\mathrm{M} 0$ adalah 13,26 $\pm 5,78 \%$ dan pada pasien M1 adalah 29,64+16,25\%. Tidak terdapat perbedaan signifikan antara mean ekspresi keduanya dengan nilai p yaitu 0,220 $(\mathrm{p}>0,05)$. 
Berdasarkan stadium klinis, didapatkan 4 pasien dengan stadium III, 8 pasien dengan stadium IVa, dan 3 pasien dengan stadium IVb. Nilai mean IL-6 pada pasien dengan stadium III, IVa, dan IVb berturut-turut adalah $45,89 \pm 22,23 \%, 46,37 \pm 17,56 \%$, dan $72,19 \pm 7,22 \%$. Nilai mean STAT3 pada pasien dengan stadium III, IVa, dan IVb berturutturut adalah $13,99 \pm 7,58 \%, 12,89 \pm 5,24 \%$,
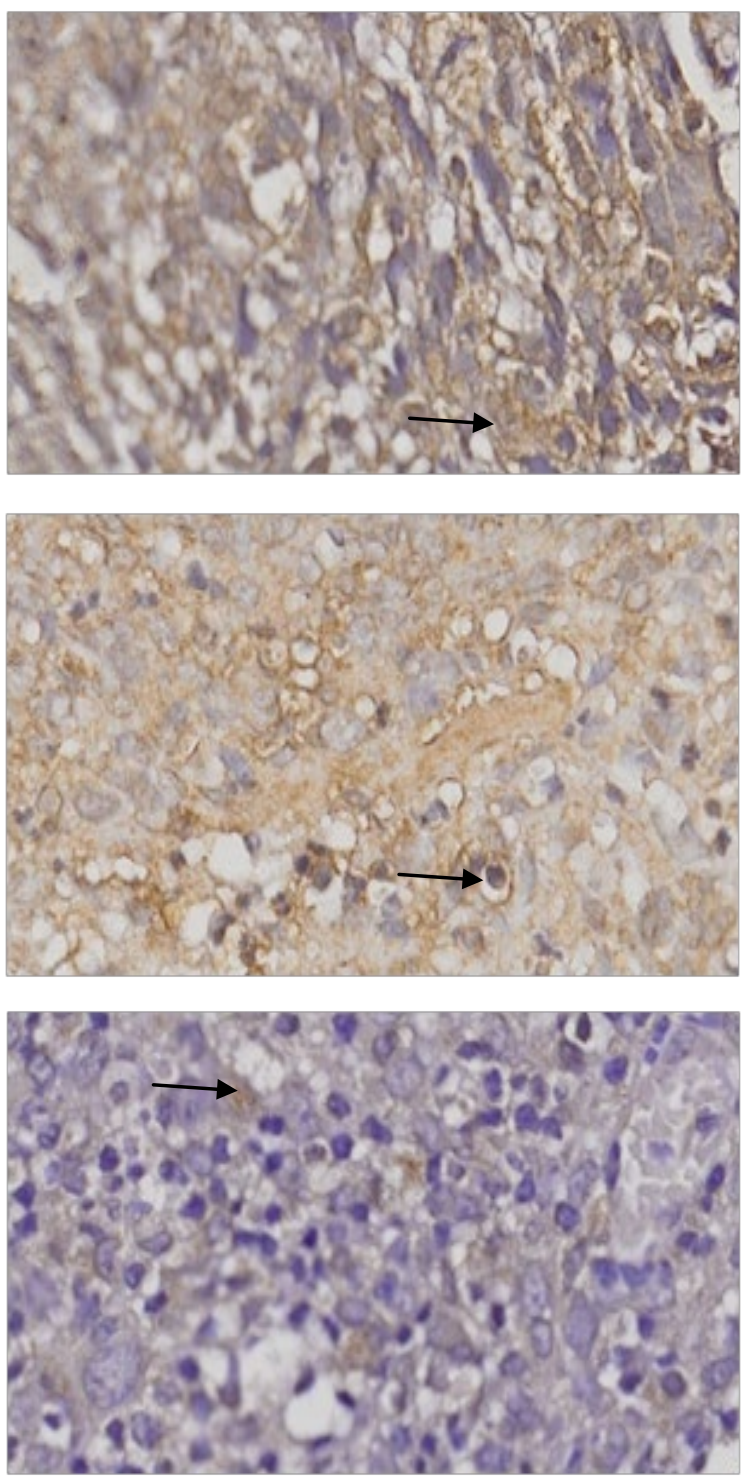

Gambar 1. Ekspresi LMP-1, IL-6 dan STAT3. (A) Ekspresi LMP-1 di membran sel dan sitoplasma (terpulas coklat, tanda panah); (B) Ekspresi IL-6 di membran sel, sitoplasma, dan celah antar sel (terpulas coklat, tanda panah) sebanyak 84.3\%, dan ekspresi STAT3 (C) di sitoplasma dan inti (terpulas coklat, tanda panah) sebanyak 47,2\% dinilai dengan perangkat lunak ImmunoRatio. dan 29,64_16,25\%. Dari hasil uji tes Oneway ANOVA tidak didapatkan perbedaan signifikan mean dari ekspresi IL-6 $(\mathrm{p}=0,116)$ antara pasien dengan stadium III, IVa, dan $\mathrm{IVb}$, sedangkan ekspresi STAT3 di antara pasien dengan stadium III, IVa, dan IVb didapatkan perbedaan yang signifikan dengan nilai $\mathrm{p}=0,038$.

\section{DISKUSI}

LMP-1 diketahui merupakan onkogen utama dalam KNF. Ekspresi LMP1 menyebabkan invasi dan metastasis KNF yang dibuktikan dari berbagai macam penelitian bahwa LMP-1 terlibat dalam regulasi ekpresi berbagai protein yang dikaitkan terhadap metastasis dengan memicu jalur pertahanan hidup dan jalur proliferasi sel. ${ }^{6}$ LMP-1 juga menstimulasi ekspresi faktor pertumbuhan sitokin, dan kemokin yang dapat memengaruhi perilaku sel epitel. Sitokin pro inflamasi ini diketahui memodulasi migrasi dan proliferasi sel epitel. Induksi interleukin (IL-1/6/10) dan sitokin pro inflamasi lain dapat melindungi ekspresi sel dari apoptosis melalui aktivasi NF-kB dan STAT3. ${ }^{5}$

Pada sel tumor, aktivasi STAT3 dapat disebabkan oleh sinyal autokrin dan parakrin IL-6 yang abnormal serta terus menerus. Namun, aktivasi STAT3 pada KNF khususnya akibat infeksi EBV belum diketahui secara jelas. Ekspresi LMP-1 dikatakan tidak berkaitan secara langsung menyebabkan peningkatan STAT3. LMP-1 diketahui memiliki elemen yang berespon terhadap STAT3. STAT3 ini justru diyakini menginduksi LMP-1 yang selanjutnya akan menyebabkan upregulasi produksi IL-6 yang juga dapat mengaktivasi STAT3. ${ }^{15}$

Sampel dalam penelitian ini berjumlah 15 subjek. Seluruh subjek penelitian merupakan penderita KNF baru dengan histopatologi WHO tipe III. Terlebih dahulu dilakukan pewarnaan IHK LMP-1 pada jaringan nasofaring penderita, dan keseluruhan subjek 
mempunyai hasil positif. Sebanyak 12 subjek penelitian $(80 \%)$ adalah laki-laki dan 3 subjek (20\%) adalah perempuan. Didapatkan perbandingan laki-laki:perempuan adalah 4:1.

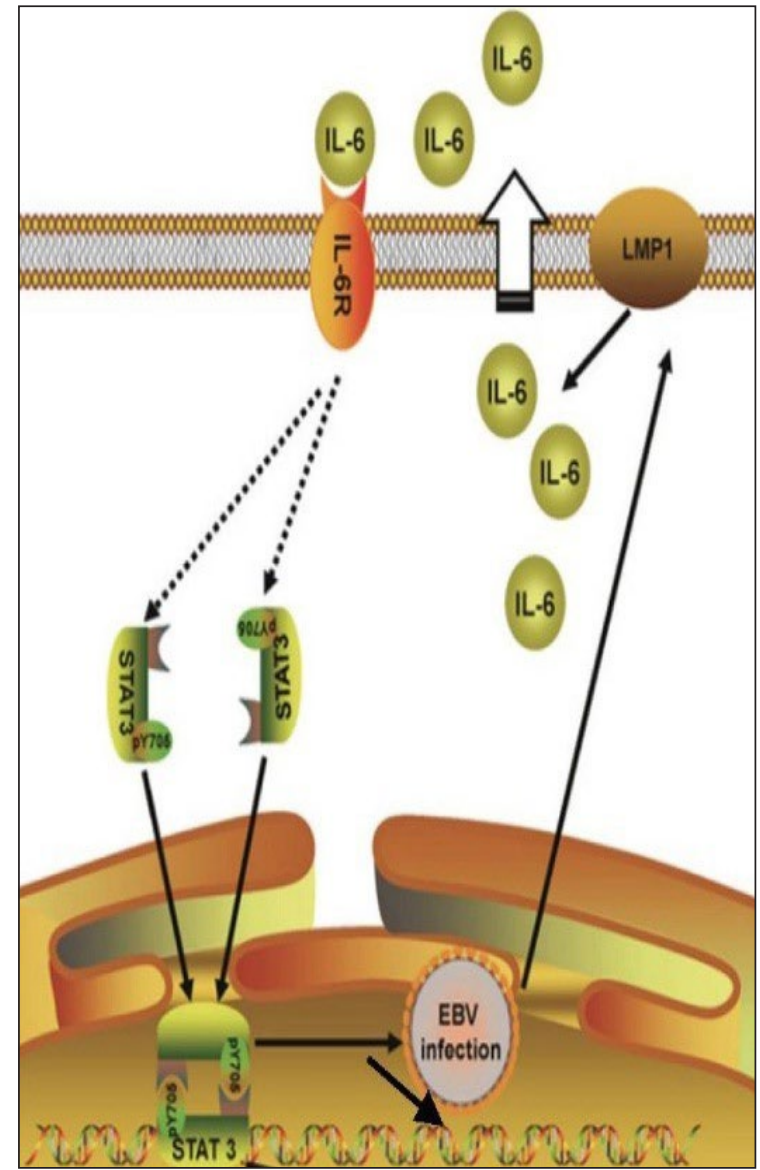

Gambar 2. Jalur sinyal IL-6/ STAT3. Dikutip dari Zhang et al. ${ }^{15}$

KNF terutama terjadi pada laki-laki, dan data di Indonesia tahun 2008 menunjukkan bahwa insiden kasus baru KNF pada laki-laki dibandingkan perempuan sebanyak 9,4:3,8. Berbagai penelitian menyebutkan bahwa kebiasaan seperti merokok dan paparan zat berbahaya dari pekerjaan menjadi penyebab insiden KNF lebih tinggi pada laki-laki dibandingkan dengan perempuan. Faktor intrinsik seperti hormon dianggap memberikan dampak lebih sedikitnya kejadian KNF pada perempuan. Hormon estrogen diketahui memiliki peran memediasi inhibisi respon inflamasi yang merupakan faktor penting pada karsinogenesis..$^{1,3,16,17}$
Subjek pada penelitian ini terbanyak adalah kelompok lansia awal (46-55 tahun) sebesar 46,66\%. Berdasarkan data epidemiologi di Cina dan Iran, insiden KNF didapatkan mulai meningkat pada usia 29 hingga 35 tahun dengan puncak pada usia 50-64 tahun. Sebanyak 60\% subjek memiliki kebiasaan makan ikan asin. Beberapa faktor kebiasaan dan gaya hidup yang diyakini memberi pengaruh pada kejadian KNF adalah kebiasaan makan ikan asin atau makanan yang diawetkan, yang dikaitkan dengan kandungan zat karsinogenik yaitu nitrosamin. Konsumsi makanan tersebut sejak usia anakanak berkontribusi meningkatkan risiko terjadinya KNF. ${ }^{1,16,18,19}$

Sebanyak 60\% subjek memiliki kebiasaan merokok. Faktor lain yang juga diduga memegang peranan penting dalam patogenesis KNF termasuk faktor lingkungan yaitu paparan dari pekerjaan dan formaldehid serta faktor kebiasaan seperti merokok. Sebanyak 11 penderita subjek penelitian bekerja dan 7 diantaranya bekerja sebagai petani. Pada berbagai penelitian mengenai faktor-faktor risiko berbagai penyakit keganasan, didapatkan hasil bahwa pekerjaan yang dapat meningkatkan faktor risiko adalah petani karena seringnya terpapar bahan pestisida. ${ }^{20,21}$

Terdapat peningkatan ekspresi baik dari IL-6 maupun STAT3 pada jaringan nasofaring penderita KNF WHO tipe III LMP-1 positif. Penelitian oleh Tsang et al. ${ }^{15}$ menunjukkan bahwa stroma KNF kaya akan sel inflamasi sehingga menjadi sumber sitokin pro-inflamasi yang memengaruhi keselamatan sel dan properti ganas dari sel tersebut. Peningkatan IL-6 juga didapatkan pada serum penderita dengan kanker yang diasosiasikan dengan prognosis yang lebih buruk. ${ }^{12}$ Penelitian meta-analysis oleh Shaozhong et al. ${ }^{22}$ pada pasien dengan kanker gaster dan penelitian meta-analysis oleh $\mathrm{Wu}$ et al. ${ }^{23}$ pada pasien dengan tumor solid, keduanya mendapatkan ekspresi STAT3 positif meningkat berapapun nilai imunoreaktifnya. 
Stadium klinis subjek penelitian ini dilihat dari nilai $\mathrm{T}, \mathrm{N}$, dan $\mathrm{M}$ yang mengacu kepada AJCC 2017, paling banyak adalah stadium IVa sebesar 53,33\%. Nilai N paling banyak yaitu N3 (53,33\%) dan jumlah subjek dengan metastasis jauh (M1) sebanyak 20\% (lihat tabel 2). Penderita KNF dapat datang dengan satu atau lebih gejala yang dikaitkan dengan lokasi tumor primer, infiltrasi ke struktur sekitar nasofaring, atau metastasis kelenjar getah bening servikal. Gejala yang paling sering menyebabkan penderita datang untuk berobat adalah benjolan pada leher yang tidak nyeri terutama mengenai regio II, III, dan IV. Metastasis jauh KNF umumnya jarang terjadi. Mayoritas penderita KNF terdiagnosa pada saat tumor sudah pada stadium lanjut karena gejala yang tidak spesifik. ${ }^{1}$

Korelasi antara ekspresi IL-6 dengan ekspresi STAT3 pada jaringan biopsi penderita KNF WHO tipe III LMP-1 positif pada penelitian ini menunjukkan semakin tinggi ekspresi IL-6, maka hal itu akan diikuti oleh ekspresi STAT3 yang juga tinggi. Demikian sebaliknya, semakin rendah ekspresi IL-6, maka hal itu juga akan diikuti oleh ekspresi STAT3 yang lebih rendah. Berbagai penelitian membuktikan banyak faktor yang terlibat dalam patogenesis KNF yang berkaitan dengan infeksi EBV. Aktivasi STAT3 ditandai dengan adanya peningkatan ekspresi STAT3 yang telah dilaporkan lebih dari $70 \%$ pada spesimen KNF. Pada kondisi fisiologis, aktivasi STAT3 diregulasi secara ketat. Pada sel tumor, aktivasi STAT3 disebabkan oleh sinyal autokrin dan/atau parakrin yang abnormal dan terus-menerus termasuk dari IL-6. ${ }^{15}$

IL-6 mengaktivasi STAT3 setelah berikatan dengan reseptornya yaitu IL6R yang akan mengaktivasi JAK lalu menginduksi fosforilasi dan dimerisasi STAT3 menyebabkan teraktivasinya STAT3. STAT3 yang telah aktif mengalami translokasi menuju nukleus untuk menginduksi transkripsi gen target. ${ }^{15}$ Terminasi dan modulasi jalur sinyal
IL-6-JAK-STAT3 dimediasi oleh suppressor of cytokine signaling (SOCS) sebagai umpan balik penghambat dan protein inhibitor of activated STAT3 (PIAS). Peningkatan jumlah dari pSTAT3 tidak diakibatkan mutasi pada STAT3 tapi berasal dari pasokan berlebih faktor pertumbuhan atau sitokin (IL-6) di dalam lingkungan mikro tumor. ${ }^{7,24}$

Penelitian ini menunjukkan bahwa ekspresi IL-6 pada jaringan nasofaring penderita KNF WHO tipe III LMP-1 positif yang belum bermetastasis jauh lebih rendah secara signifikan dibanding dengan yang sudah bermetastasis jauh. Penelitian pada pasien dengan karsinoma sel skuamosa rongga mulut oleh Jinno et al. ${ }^{14}$ menunjukkan bahwa peningkatan ekspresi IL-6 lebih terlihat pada spesimen pasien yang sudah mencapai stadium lanjut, pasien dengan metastasis regional, atau metastasis jauh. Epithelialmesenchymal transition (EMT) merupakan proses kunci dalam jalur metastasis suatu tumor yang ditandai dengan hilangnya hubungan dan perlekatan antar sel sehingga terjadi perubahan dalam properti invasi dan migrasi. Ekspresi berlebih IL-6 pada sel tumor menunjukkan peningkatan terjadinya metastasis regional atau metastasis jauh. Hal ini membuktikan fungsi IL-6 dalam memediasi EMT sel tumor kepala leher dengan potensi metastasisnya. ${ }^{21}$ IL-6 juga terbukti dapat mempromosikan migrasi dan invasi dari sel kanker dan meningkatkan ekspresi MMP khususnya MMP-2 dan MMP9. Tingginya ekspresi MMP-2 berkorelasi dengan buruknya angka ketahanan hidup pada KNF, sedangkan tingginya ekspresi MMP9 berhubungan dengan metastasis kelenjar getah bening. ${ }^{7}$

Penelitian ini menunjukkan terjadinya peningkatan ekspresi STAT3 pada penderita KNF WHO tipe III LMP-1 positif yang bermetastasis jauh dibandingkan dengan yang belum bermetastasis jauh, namun hasil tersebut tidak signifikan secara statistik. Fungsi intrinsik tumor dari aktivasi STAT3 
termasuk diferensiasi, perluasan sel puncak kanker, proliferasi (dengan menstimulasi transkripsi cyclin D1, cdc2, c-myc, cyclinB1, $c-j u n, c F o s$, dan greb1), apoptosis (upregulasi ekspresi $B C L-2, B C L-x L, M C L-1, B C L-w$, dan survivin), dan respon terhadap hipoksia

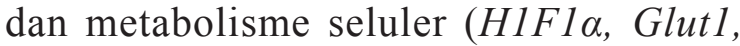
Hsp70, Hsp90, p21, dan Cdc2). Jalur JAK/ STAT3 juga meregulasi aspek ekstrinsik tumor dalam tumorigenesis termasuk angiogenesis (regulasi transkripsi VEGF dan HIF la), keselamatan sel endotel dan neovaskularisasi, infiltrasi sel imun, aktivasi sel mesenkimal, dan metastasis. ${ }^{25}$ Penelitian meta analysis oleh Wu et al. ${ }^{23}$ pada berbagai tumor solid menunjukkan peningkatan ekspresi STAT3 berkaitan dengan buruknya prognosis penderita.

Aktivasi STAT3 dapat meningkatkan ekspresi MMP yang diketahui berkontribusi dalam invasi tumor, angiogenesis, dan metastasis. Penelitian oleh Siveen et al. ${ }^{11}$ melaporkan bahwa aktivasi STAT3 yang berlebih berkorelasi dengan invasi dan metastasis berbagai keganasan. Penelitian oleh Kesanakurti et al. ${ }^{8}$ yang menjadikan STAT3 sebagai gen target dan blokade aktivitas STAT3 menunjukkan penurunan aktivitas MMP-2 dan MMP-9 pada kasus kanker paru dan glioma sehingga terjadi inhibisi proliferasi, invasi, dan migrasi, serta apoptosis.

Kesimpulan penelitian ini adalah terdapat peningkatan ekspresi IL-6 dan STAT3 pada jaringan nasofaring penderita KNF WHO tipe III LMP-1 positif. Semakin tinggi ekspresi IL-6 maka ekspresi STAT3 pada jaringan nasofaring penderita KNF WHO tipe III LMP-1 positif semakin meningkat. Semakin tinggi stadium klinis, maka ekspresi STAT3 pada jaringan nasofaring penderita KNF WHO tipe III LMP-1 positif akan meningkat. Namun peningkatan ekspresi IL-6 tidak signifikan secara statistik. Diperlukan penelitian lebih lanjut mengenai faktor lain yang terlibat dalam jalur sinyal JAK/STAT.

\section{DAFTAR PUSTAKA}

1. Wei WI, Chua DTT. Nasopharyngeal Carcinoma. In: Johnson JT, Rosen CA, editors. Bailey's Head and Neck Surgery Otolaryngology. 2. 5 ed. Philadelphia: Lippincot Williams \& Wilkins; 2014. p. 1875-97.

2. Lun SW-M, Cheung ST, Cheung PFY, To K-F, Woo JK-S, Choy K-W, et al. CD44+ cancer stem-like cells in EBV-associated nasopharyngeal carcinoma. PloS one. 2012;7(12):e52426.

3. Sudiono J, Hassan I. DNA EpsteinBarr virus (EBV) sebagai biomaker diagnosis karsinoma nasofaring. Dental Journal (Majalah Kedokteran Gigi). 2013;46(3):140-7.

4. Kentjono WA. Perkembangan terkini penatalaksanaan karsinoma nasofaring. KOMPILASI. 2013.

5. Dawson CW, Port RJ, Young LS, editors. The role of the EBV-encoded latent membrane proteins LMP1 and LMP2 in the pathogenesis of nasopharyngeal carcinoma (NPC). Seminars in cancer biology; 2012: Elsevier.

6. Zhao Y, Wang Y, Zeng S, Hu X. LMP1 expression is positively associated with metastasis of nasopharyngeal carcinoma: evidence from a meta-analysis. Journal of clinical pathology. 2012;65(1):41-5.

7. Guo Y, Xu F, Lu T, Duan Z, Zhang Z. Interleukin-6 signaling pathway in targeted therapy for cancer. Cancer treatment reviews. 2012;38(7):904-10.

8. Kesanakurti D, Chetty C, Dinh DH, Gujrati M, Rao JS. Role of MMP-2 in the regulation of IL-6/Stat3 survival signaling via interaction with $\alpha 5 \beta 1$ integrin in glioma. Oncogene. 2013;32(3):327.

9. Sun W, Liu D-B, Li W-W, Zhang L-L, Long G-X, Wang J-F, et al. Interleukin-6 promotes the migration and invasion of nasopharyngeal carcinoma cell lines and upregulates the expression of MMP-2 and MMP-9. International journal of oncology. 2014;44(5):1551-60.

10. Pan T, Xu J, Zhu Y. Self-renewal molecular mechanisms of colorectal cancer stem cells. International journal of molecular medicine. 2017;39(1):9-20. 
11. Siveen KS, Sikka S, Surana R, Dai X, Zhang J, Kumar AP, et al. Targeting the STAT3 signaling pathway in cancer: role of synthetic and natural inhibitors. Biochimica et Biophysica Acta (BBA)-reviews on cancer. 2014;1845(2):136-54.

12. Kitagawa N, Kondo S, Wakisaka N, Zen Y, Nakanishi Y, Tsuji A, et al. Expression of seven-in-absentia homologue 1 and hypoxia-inducible factor 1 alpha: novel prognostic factors of nasopharyngeal carcinoma. Cancer letters. 2013;331(1):527.

13. Chen Y-P, Zhang W-N, Chen L, Tang L-L, Mao Y-P, Li W-F, et al. Effect of latent membrane protein 1 expression on overall survival in Epstein-Barr virus-associated cancers: a literature-based meta-analysis. Oncotarget. 2015;6(30):29311.

14. Jinno T, Kawano S, Maruse Y, Matsubara R, Goto Y, Sakamoto T, et al. Increased expression of interleukin-6 predicts poor response to chemoradiotherapy and unfavorable prognosis in oral squamous cell carcinoma. Oncology reports. 2015;33(5):2161-8.

15. Zhang G, Tsang CM, Deng W, Yip YL, Lui VW-Y, Wong SCC, et al. Enhanced IL-6/IL-6R signaling promotes growth and malignant properties in EBVinfected premalignant and cancerous nasopharyngeal epithelial cells. PloS one. 2013;8(5):e62284.

16. Zhang L-F, Li Y-H, Xie S-H, Ling W, Chen S-H, Liu Q, et al. Incidence trend of nasopharyngeal carcinoma from 1987 to 2011 in Sihui County, Guangdong Province, South China: an age-periodcohort analysis. Chinese journal of cancer. 2015;34(3):15.

17. Xie S-H, Yu IT-S, Tse L-A, Mang OW-k, Yue L. Sex difference in the incidence of nasopharyngeal carcinoma in Hong Kong 1983-2008: suggestion of a potential protective role of oestrogen. European Journal of Cancer. 2013;49(1):150-5.

18. Wei K-R, Zheng R-S, Zhang S-W, Liang Z-H, Ou Z-X, Chen W-Q. Nasopharyngeal carcinoma incidence and mortality in China in 2010. Chinese journal of cancer. 2014;33(8):381.

19. Safavi-Naini A, Raad N, Ghorbani J, Chaibakhsh S, Ramezani-Daryasar
R. Incidence trends and geographical distribution of nasopharyngeal carcinoma in Iran. Iranian journal of cancer prevention. 2015;8(1):24.

20. Wu L, Li C, Pan L. Nasopharyngeal carcinoma: A review of current updates. Experimental and therapeutic medicine. 2018;15(4):3687-92.

21. Kachuri L, Harris MA, MacLeod JS, Tjepkema M, Peters PA, Demers PA. Cancer risks in a population-based study of 70,570 agricultural workers: results from the Canadian census health and Environment cohort (CanCHEC). BMC cancer. 2017 Dec;17(1):343.

22. He S, Liao G, Liu Y, Huang L, Kang M, Chen L. Overexpression of STAT3/pSTAT3 was associated with poor prognosis in gastric cancer: a meta-analysis. International journal of clinical and experimental medicine. 2015;8(11):20014.

23. Wu P, Wu D, Zhao L, Huang L, Shen G, Huang J, et al. Prognostic role of STAT3 in solid tumors: a systematic review and metaanalysis. Oncotarget. 2016;7(15): https:// www.ncbi.nlm.nih.gov/pmc/articles/ PMC4991424/

24. Colevas AD, Yom SS, Pfister DG, Spencer $\mathrm{S}$, Adelstein D, Adkins D, et al. NCCN Guidelines Insights: Head and Neck Cancers, Version 1.2018. Journal of the National Comprehensive Cancer Network. 2018;16(5):479-90.

25. Bournazou E, Bromberg J. Targeting the tumor microenvironment: JAK-STAT3 signaling. Jak-Stat. 2013;2(2):e23828. 